\title{
SUBSTANTIATION OF EARLY TEACHING OF TECHNICAL AND TACTICAL TRAINING IN GIRLS BOXING
}

\author{
Artur Vorontsov \\ Postgraduate Student, Zaporizhzhia National University, Ukraine \\ e-mail: vai77@ukr.net, orcid.org/0000-0002-3269-273X
}

\section{Summary}

The article presents the substantiation of early training of technical and tactical training of girls who deal with boxing. Methods. Theoretical analysis of special and scientific literature, educational programs on sports and combat martial arts, generalization of data. Results. Considered: World trends in sports in general in gender, the chronology of the formation of women's boxing in the world, trends in the development of girls boxing in Ukraine and Europe. The theoretical analysis of physiological possibilities of girls to early mastering of techniques and tactics in boxing. Proved the ability to teach girls technical and tactical training (TTP) in boxing earlier than indicated in the training programs in boxing. It has been studied age qualification in the educational program of Children's and youth sports schools (CYSS) from admission to sports martial arts and boxing. A comparison of age qualification is made when taking on boxing and combat martial arts of girls. It have been studied normative requirements of leading countries in Europe in a girls boxing with transmitted to the following stages of preparation in the CYSS. It is determined that criteria only with the assessment of physical training and the indicated sports outcome on competitions during the year are not enough to transfer to the next year. Conclusion. The results of the theoretical analysis have proved to be expedient to decrease the age qualification for girls when enrolled to the boxing department of CYSS. It has been determined the great consideration of TTP level when transferring to the next year of study in the CYSS. The need to create author's techniques for assessing TTP in girls.

Keywords: Girls training, evaluation methods, pedagogical approach, women's boxing.

DOI: https://doi.org/10.23856/4711

\section{Introduction}

Masculinization of society in recent years is significantly amplified and sport is not an exception. Increasingly, women choose the sports which were considered to be inherent in men. Boxing as one of the most popular sports increasingly becomes attractive to the female gender. Increasing attention from the side of the media raises the social status of a boxer woman, thanks to which the objective integration into social life is growing (Konokh \& Vorontsov, 2021: 7-10). The success of Ukrainian women's boxers in competitions of different levels, including in the international arena, enhance motivation to classes in girls from earlier age. But in educational programs for receiving a boxing office to children's and youth sports school (CYSS) of Ukraine, such norms do not meet world social aspiring and interest in the development of this sport. The Purpose of The Study: It is to prove the expediency of lowering the age qualification for girls when reception to the box office in the CYSS. Material \& methods. To find out the problem field of the selected topic, the determination of the object, subject, the purpose and substantiation of the results used the method of the theoretical analysis of special and scientific literature, the Internet, generalization of data. 
Implementation of this method was carried out by analyzing and generalizing the data of scientific literature and experience in domestic and foreign practices on the preparation of athletes, regardless of sex in various sports and boxing. The study and generalization of scientific literature on the subject of the article was carried out according to educational and methodical manuals, scientific articles of professional scientific journals, materials of conferences, dissertation and dissertation robots, leading scientific Internet resources.

\section{Prerequisites for the development of girls boxing}

Recently, more and more female gender are interested in sports starting from amateur sports and ending with professional. The number of women participating in the highest rank competition has increased. According to specialists, the number of women in the last 30 Olympiad has increased by $800 \%$. The number of women representing the countries of the Middle East and North Africa is constantly increasing. According to statistical data in 1896 Olympic Games in Athens, women had no admission to the competition, later in 1952 in Helsinki women's gender representatives were already $10.5 \%$. In Beijing at the 2008 Olympic Games, the number of women participants increased by $40 \%-42.05 \%$ according to various data in London at the 2012 Olympic Games increased to $44.7 \%$ of the total number of athletes. In the Olympic Games Tokyo -2020 , the share of women will be $48.8 \%$, and at the Olympic Games in Paris - 2024 on the recommendation of the IOC it is planned to achieve an equal number of athletes of men and women. Gaining women with increasing sports including traditionally "male", contributed to the expansion of the Olympic Games Program. In Paris, on the II Olympic Games in 1900, women first took part in two sports programs: golf and tennis. Next, they submitted such a purely "Men's" sports as: Football at the Atlanta 1996, Taekwondo and Heavy Athletics at the Olympics in Sydney in 2000, the struggle is free to the Olympiad in Athens in 2004, Boxes at the Olympiad in London 2012. According to the statistics of the two last Olympic Games of 2012 and 2016, women presented in 5 programs on sports martial arts, 6 possible. In some types, compared to the number of participants with men (Taekwondo), some began to take the lead in the number of female athletes (fencing), in other types of OI programs from sports martial arts (freestyle wrestling and judo) tendency to increase in the number of women participants. Although it is a sign of the adoption of a female Boxing in the OI-2012 program, at the Olympic Games of 1904, there was a demonstration boxing battle among women in this sport, but developing a woman's boxing has not received, moreover, was banned in some countries.

The revival of female boxing at the official level is associated with the Swedish Boxers Association and the British Association of Boxers-Amateurs who conducted in turn competitions for women's boxers in 1988 and 1997. At the end of 1998, the AIBA Congress (World Amateur Boxing Association) decided to develop women's boxing. Despite the fact that the Olympic program from women's boxing at the beginning took place in three weight categories, and from the following games to Tokyo will be already in five weight categories, which is still less than men, but in the long run, in Paris, it will be added to Paris one weight category in women. In 2021 in Saudi Arabia, the first training of Boxing Female Trainers (Konokh \& Vorontsov, 2019: 115-119) was held.

Thanks to the above-described actions women's boxing began to develop rapidly. More classification competitions internationally, international tournaments and joint training fees have increased. Also increased the number of competitions within the country, which contributed to the popularization of this sport among girls and more attention from sports functionaries. Thus, the issue of the development of the youngest age groups of female boxing in order to prepare 
the reserve in the future and strengthening the international image of Ukraine as a "boxing state" in competitions of these age groups in the future.

In 2017, the First Boxing Championship of Ukraine was held among girls 12-13 years old, that is, 2004-2005 years of birth. Then in 2018 a qualifying championship of Ukraine was held to identify candidates for participation in the first championship of Europe on this age group, by that time the girls began such official competitions for 14 years. It indicated the disadvantages in technical and tactical training and forced to review in general the training process of girls engaged in this sport.

To the opinion of the author, a similar situation was already in boxing practice in the middle 70s of the last century, when the selection at the boxing department was for boys from 14 years old, and later in 1975, the age cense was reduced to 12 years old and coaches needed to change teaching approaches to technical and tactical preparation of boxers.

3. Analysis of age qualification and regulatory requirements in educational programs of sports martial arts in children's and youth sports schools

In connection with the conducting of the country's championships held from 12 years and the popularity of women's boxing to classes for this sport, more and more girls are moving from other sports and martial arts. One of the reasons for such a transition to Box's class is that some types of martial arts are allowed to classes and various rank of girls tournaments with a smaller age-older than in boxing, so the greater number of girls at the beginning of their sports career a martial board forced to go to other species sporting and martial arts. Subsequently, when the age-old process allows you to engage and take part in boxing competitions there is a transition to this sport. But this is not always positively displayed on boxing and coaching techniques for a long period of time to make their adjustments to technical actions, and in some cases to radically change. Therefore, the author had an assumption of a decrease in the age qualification for girls when taking a boxing office in children's and youth sports schools (CYSS) for this purpose, a visual qualification for girls when reception in other types of contact martial arts.

In the review of educational programs for sports and national units for the CYSS approved by the Ministry of Youth and Sports of Ukraine, it was to consider the age-old training program in the initial training group on the department of contact martial arts such as: the Ukrainian martial art "Spas" - the age of enrollment 7-8 years, Taekwondo WTF - age enrollment 7 years old, Horting (modern Ukrainian martial art) - age enrollment 6-8 years old, Kickboxing WAKO - age enrollment 7-8 years old, Pankration - age enrollment for 8 years, Thai boxing Age of enrollment 10 years, Handwritten battle - Age of enrollment for 8 years, MMA (mixed martial arts) - age enrollment 8-9 years old, boxing (girls) - age of 10 years.

Age qualification at sports schools at the boxing department in the main competitor of the Ukrainian national team in the girls boxing in Europe, the teams of Russia are the same as in our CYSS. Given the current trends in the development of women's boxing, especially its younger groups, a dance calendar of sports competitions, educational-training fees also research in sports medicine, psychology and physiology, it should be assumed that there is a meaning of decline in the age-olds for girls when counting on boxing department in the CYSS. This will contribute to an increase in the popularization of the sport, gender equality, improvement of technical and tactical training, the development of physical qualities that have sensitive development periods and will be needed over time at the stage of many years of training. What will greatly increase the techno tactical potential of girls in participation in European championships in their age groups.

Specialists from boxing pay attention to the fact that in Russian Children Sports Schools when transferring from one academic year, the next is not taken into account in the transitional 
standards of TTP, and in the priority of physical training and participation in competitions. It has payed attention to the rapid drop in contingent at $60 \%$ in basic preparation groups. It has been bent with an imperfect system for evaluating TTP, believes that it should be based not on separate indicators, but on integral motor activities. They offer to increase the efficiency of the TTP system approach, by introducing new elements or changed internal connections between existing elements (Vorontsov, 2020: 10-18).

Belarus boxing specialists give statistics in which 2-5\% of the pupils in the sport are 2-5\% of the pupils, the level of detachment in the basic training groups is $30 \%$. Such an indicator, at their opinion, violates the continuity of TTP. It determines that after 3 years of study, the actual individualization and in-depth training specialization (Vorontsov, 2020: 10-18).

In the domestic CYSS, the level of mastery of TTP, when transferring to further stages of study, is also not taken into account in transient norms. The main indicator for the transfer of the student for the next stage of preparation is the implementation of physical preparation standards and the result shown in competitions.

That is, according to the author of the article, the issues of the integral assessment of the TTP in educational programs for sports school are introduced. The expediency of evaluating technical and tactical training through copyright techniques in order to more interest in sports, which will also contribute to a lesser discharge of the contingent and increase the percentage of TTP continuity.

\section{Analysis of psychophysiological features of the female organism}

After studying Guba, Tarpishev \& Samojlov (2003), Ivashchenko \& Bezkopylnyi (2006), Lyah (2006), Nikitushkin (2009), Farfel (2011), Rumyansva \& Soha (2012), Van Syaohan (2017), Ivashchenko O. (2017), Shahlina \& Kovalchuk (2018), Zemtsova (2019), Shakhlina \& Shystiakova (2020) Fundamental scholars, modern results of researches of specialists in dirls sports, as well as physiologists, the author of the article selected the most significant indicators on which should be to build early TTP.

According to the data of scientists, the early start of intense muscle activity creates the most acceptable conditions for the development of a female body in the future, subject to adequate construction of a training process, taking into account the individual physiological features of the female body with obligatory control of a medical worker and trainer.

Observations of specialists show that the motor activity of girls from 9 to 13 years is especially large, the younger and middle-age groups are not inferior to this guys. The achievement of motor maturity is ahead of achievements of sexual maturity, as you know, she is in girls.

Specialists, determine that girls have average volume of lokomogs from $6.4-7.7 \mathrm{~km} /$ day, boys from $7.1-9.0 \mathrm{~km} /$ day, advantage over the genetic level "Slow fibers" in muscles. It draws attention to that these fibers are needed for long and moderate to the intensity of physical activity.

The study of a scientist in complicated coordination from 7-8 years to 12-13 years has proven that the interest assimilation of physical exercises in children greatly increases, after it remains in place.

According to these physiologists, the development of a pace of cardiac-vascular system of girls in a preschool and younger school age is a more than of guys. The hormonal system has a second increase and is expressive in 9 years. That of some way provide an anabolic effect to the body as a whole.

Specialists prove that the period to develop motility in order to create a reliable foundation from 3 to 10 years. 
Scientists, mark a high motor maneuverability, ingenuity, capability to combine motor tasks from 8 years. It is noted that the development of such physical quality as agility in this age in the future practically does not develop.

According to the scientist, by the number of repetitions in power exercises in girls can be as guys, but less by muscle tension. Girls at this age are not lagging behind boys in physical training if their motor mode is optimal. The important qualities are formed: a sense of time, space, muscle sensation, control of the degree of voltage and relaxation. In general, younger school age contributes to developing agility and flexibility.

Specialists determine sensitive periods of development in children of such qualities as: general endurance from 9-11 years, reaction rate from 9-11 years. It is noted that it is necessary to work purposefully on the development of the reaction to 12 years. Allocate age 4-9 as the largest increase in the frequency of movements, 6-7 years of arise of arbitrary regulation of movements. Improvement of coordination mechanisms of the central nervous system.

With the data of scientists, the accuracy of a single movement develops 7-11 years. The highest degree of growth of physical qualities in girls: the speed of movement of feet from 7-9 years, static equilibrium from 8-9 years. High rate of growth of physical qualities begins earlier than in boys from 7-8 years, high-speed - power extensors from 9-12 years old, static endurance of shoulder flexors from 9-10 years old, power and dynamic endurance of the trunk 9-12 years old, the growth of the pace with 8-9 years old.

Specialists note the development of a disposable speed from 7-8 years to 13-14 years, then a sharp deceleration of development, from 8-11 years endurance of the knife leg muscles increases by $77 \%$, trunk extensors by $85 \%$, forearm extensors by $41 \%$, power endurance in girls from 9-11 years old reaches the 15th anniversary girls.

A scientist determines that the increased volume of physical activity in girls can be in 8 years, the volume of high-speed-power loading and speeds more than in boys in 8-9 years, whiter gain of agility and flexibility.

A scientist, establishes a relationship between coordination abilities, physical development, air conditioning and body length. It determines that they are most related to acyclic locomogues of girls at 9 and 13 years. The development of larger coordination abilities in absolute and relative indicators except ballistic accounts for 7-9 years. A generalized analysis of experimental studies proved in 7-11, 12 years of coordination has been achieved in the future.

The above mentioned material (Vorontsov, 2019: 35-48) proves the physiological readiness of the maiden organism to physical loads in boxing in boxing with a much early age period. That allows you to further accelerate the mastery of certain, basic elements of boxing.

By linking the empirical data of these studies with the box preparation for CYSS, where in the initial training teams 1 and 2, training recommends learning of single direct strikes and protecting from them with the help of the trunk or the palm stand prove that such work out of boxing Techniques are possible from earlier age. The author of the article connects this with the fact that the reaction faction develops in 9 years, power and dynamic endurance of the trunk develops from 8-12 years, the accuracy of a single movement from 7-11 years old, improving the coordination mechanisms of the central nervous system of 7-8 years, that is, the The task is possible to work effectively in these years. Sexual Periods of Foot Rate in girls 7-9 years and speed-strength quality of the feet of 9-12 years, as well as the endurance of the spacecraft of the muscles will allow to assimilate the technique of special boxing transfers. 


\section{Conclusions}

The results of the theoretical analysis have proved to be expedient to decrease the age qualification for girls when enrolled to the boxing department of CYSS. Determined the consideration of TTP level when transferring to the next year of study in the CYSS. The need to create author's techniques for assessing TTP of girls.

\section{References}

1. Konoch, A., Vorontsov, A. (2021). Definition of gender identity in younger age groups of women's boxing. Scientific Journal of National Pedagogical Dragomanov University. Series 15. Scientific and pedagogical problems of physical culture (physical culture and sports). 7(138), 7-10. DOI: 10.31392/NPU-nc.series 15.2021.7(138).01 [in English].

2. Konokh, A. \&Vorontsov, A. (2019). Obuchenie tehniko-takticheskoj podgotovke devochek $v$ gruppah bazovoj podgotovki po boksu [Teaching technical and tactical training for girls in basic training groups in boxing]. Fizychne vykhovannia i sport $v$ navchalnykh zakladakh Ukrainy na suchasnomu etapi: stan, napriamky ta perspektyvy rozvytku 2019 [Proceeding's of the Physical education and sport's in primary school's of Ukraine at the present: stage, state, directions and prospect's of development 2019] Kharkiv : Ozerov G.V.,115-119. [in Russian]. 3. Vorontsov, A.I. (2019). Analiz vozrastnogo cenza devochek v uchebnoj programme po boksu dlya dyussh. [Analysis of the age qualification of girls in the boxing curriculum for youth]. Aktualni problemi fizichnogo vihovannya riznih verstv naselennya [Current problems of physical education of different segments of the population] Kharkiv: Kharkivska derzhavna akademiia fizychnoi kultury, 35-48. Retrieved from: http://journals.uran.ua/hdafk-tmfv [in Russian].

4. Vorontsov, A. (2020). Suchasni metody otsinky tekhniko-taktychnykh dii divchat u boksi. [Methods of assessment of technical and tactical actions in boxing of girls].Visnyk KamianetsPodilskoho natsionalnoho universytetu im. Ivana Ohiienka. Fizychne vykhovannia, sport $i$ zdorovia liudyny. № 19. P. 10 - 18. doi: 10.32626/2309-8082.2020-19.10-17 [in Ukrainian]. 